\title{
O śląskiej szkole mikrologii (1999-2005). Garść wspomnień
}

\author{
Aleksander Nawarecki
}

\section{Małe, śląskie, czarne}

Te trzy słówka są parafrazą pamiętnej triady Brudny, zły i brzydki. Przywołuję tytuł przeboju Ennio Morricone (z filmu w reżyserii Sergio Leone) jako muzyczny emblemat „spaghetti westernu", włoskiej imitacji koronnego gatunku amerykańskiego kina, niegdyś budzącej oburzenie, a potem uznanej za zapowiedź antywesternu, a nawet dekonstrukcję klasycznej formy. Manierę tych filmów, ich przesadę bliską parodii kojarzę bowiem z naszą przygodą „mikrologiczną". Pod tym hasłem w Uniwersytecie Śląskim przez parę lat pojawiały się konferencje, debaty, magisteria i doktoraty, publikacje indywidualne i zbiorowe, w których dominowały terminy z przedrostkiem „mini” i „mikro”. Powtarzaliśmy te zaklęcia częściej niż formaliści „formę”, prascy strukturaliści „strukturę”, a genewscy krytycy „temat”. Imitacyjność tego gestu była oczywista, wszak na początku XXI wieku nikt nie spodziewał się powstania nowej szkoły chicagowskiej albo tartuskiej, ani tym bardziej śląskiej. Słynne centra literaturoznawcze nie wykuwały już epokowych metod, więc o karierach wielkich naukowych narracji myślało się z nostalgią i poczuciem rosnącego dystansu. Wyczerpał się także postmodernizm; teoria literatury uchodziła za naukę zamkniętą, zaś jej aktualną postać określano ogólnym mianem „Teorii”. Jeśli zatem skazani byliśmy na teorię „wszystkiego” i zarazem „niczego”, to może dałoby się ją uśrednić jako „teorię małego”? Dlaczego nie, skoro popularnością cieszyła się teoria „tego co napisane” (gramatologia J. Derridy) i nauka o szybkości (dromologia P. Virilio)? 
Był to pomysł filuterny i prowokacyjny zarazem, bardziej stosowny w młodym, prowincjonalnym ośrodku naukowym, niż w stołecznych uniwersytetach. Nie powinno dziwić, że studia nad tym, co drobne, błahe, znikome, a nawet nędzne znalazły u nas lepszy klimat niż w Warszawie. Nie zapominam wszakże o siostrzanej Wielkopolsce, gdzie w tym samym czasie, choć niezależnie, ukazały się dwie kluczowe, może najważniejsze książki mikrologiczne: Ewy Domańskiej Mikrohistorie. Spotkania w międzyświatach (Poznań 1999) i Przemysława Czaplińskiego Mikrologi ze śmierciq̨ (Poznań 2000). Jeśli ta mikrotendencja najgłębiej jednak zakorzeniła się w okolicach Katowic, to pewnie sprzyjał jej miejscowy grunt, a raczej jego erozja. Czarny, brudny, industrialny Śląsk miał za sobą splendor światowego centrum przemysłu ciężkiego, skończyła się gierkowska gigantomania, większość hut i kopalń została zamknięta, a największa w kraju aglomeracja raczej się atomizowała, niż rosła w metropolię. W cieniu Spodka i Superjednostki mało kto myślał o „drobiazgach”, ale być może pomogła nam aura ekonomicznej i ekologicznej rozsypki, rozdrobnienia, degradacji?

\section{Podstawowe informacje}

Faktem jest, że właśnie wtedy ukazała się seria trzech tomów: Miniatura i mikrologia literacka (Katowice 2001-2003) uzupełniona (na zasadzie „dogrywki”) zbiorem Skala mikro w badaniach literackich (Katowice 2005). Wszystkie cztery publikacje wydano w wydawnictwie Uniwersytetu Śląskiego pod moją redakcją przy udziale M. Szczęsnego, B. Mytych i M. Bogdanowskiej. Recenzentami naukowymi kolejnych tomów byli: M. Kalinowska, J. Sawicka, A. Fiut, L. Wiśniewska. Te cztery woluminy stanowią zrąb działalności „szkoły”: w sumie 1000 stron druku, 53 teksty, 40 autorów, w tym 34 związanych z UŚ i 6 gości (także z Francji i USA)ํ. Dopełnieniem była finalizowana równolegle moja książka Mały Mickiewicz. Studia mikrologiczne (Katowice 2003), a także seria dokonanych wtedy translacji (drukiem ukazały się przekłady R. Barthes'a i G. Bachelarda)². Za końcową cezurę uznaję rok 2005, lecz kilku autorów najmocniej związanych z serią budowało „na boku” własną wizję mikrologii, czego efekty ogłaszali jeszcze długo później. Janusz Ryba, koneser oświeceniowych „bibelotów”, wydał swoje w filigranowe eseje w Uwodzicielskim obliczu oświecenia (Katowice 2002). Beata Mytych studia nad śladem i tropem włączyła do „łowieckiej” monografii Poetyka i łowy. O idei dawnego polowania $w$ literaturze XIX wieku (Katowice 2004). Aleksandra Kunce „urok mikrologii” przeniosła na teren kulturoznawstwa, gdzie przedstawiła „puentylistyczny” traktat: Antropologia punktów. Rozważania przy tekstach Ryszarda Kapuścińskiego (Katowice 2008). Wioletta Bojda, autorka programowej Historii miniatury, ze znacznym poślizgiem opublikowała monografię Anny Świrszczyńskiej odkrywanie rzeczywistości (Katowice 2015), której część środkowa (140 stron) poświęcona została miniaturze. Zbigniew Kadłubek i Mariusz Jochemczyk wytrwale realizują własne projekty silezjologiczne i oikologiczne, ale zajmując się śląską „mniejszością”, mają poczucie mikrologicznych inspiracji ${ }^{3}$. Odmienną retoryką posługuje się Iwona Gralewicz-Wolny,

\footnotetext{
${ }^{1}$ Oto lista autorów: M. Bąk, W. Bojda, E. Buksa, R. Cudak, J. Dembińska-Pawelec, M. Dziaczko, A. Dziadek, P. Fast, W. Forajter, T. Głogowski, I. Gralewicz-Wolny, E. Grodzka-Łopuszyńska, R. Grześkowiak, E. Hurnikowa, P. Jędrzejko, M. Jochemczyk, Z. Kadłubek, J. Kisiel, A. Kołodziej, R. Koropeckyj, A. Kunce, J. Leociak, P. Michałowski, K. Mokry, B. Mytych, A. Nawarecki, J. Olejniczak, M. Nowotna, D. Noras, U. Paździor, M. Piotrowiak, J. Różyc-Molenda, J. Ryba, T. Stępień, A. Szawerna Dyrszka, M. Szczęsny, B. Szargot, M. Szargot, A. Węgrzyniak, S. Zając.

${ }^{2}$ Por. R. Barthes, Mitologie, przeł. A. Dziadek, Warszawa 2000; G. Bachelard, Miniatura, przeł. K. Mokry, T. Markiewka „Literatura na Świecie” 1999, nr 9.

${ }^{3}$ Kwiatki świętego Franciszka z Asyżu, przeł. L. Staff, Warszawa 1959, s. 353.
} 
publicznie ganiąc kolegów-mikrologów za lekceważenie literatury dla dzieci, autorka Uwolnić Pippi (wspólnie z B. Mytych-Forajter) nadrabia dziś z nawiązką owe „dziecinne” zaniedbania4. Ostatnim przykładem ciągłości jawi się zbiorowy tom: Balaghan. Mikroświaty i nanohistorie (red. M. Jochemczyk, M. Kokoszka, B. Mytych-Forajter, Katowice 2015). Książka opublikowana dziesięć lat po zamknięciu mikrologicznej serii stanowi jakby jej sentymentalną reaktywację. Przynosi m.in. teksty 17 autorów publikujących niegdyś w Miniaturze i mikrologii, obok „weteranów” pojawiają się nowi badacze „zanikania” i „uchyłków” - czyżby rosła generacja nanoekspertów?

\section{Miniatura i mikrologia literacka}

Wracam do kluczowej serii wydawniczej; jej trzon autorski stanowiły osoby zatrudnione w Zakładzie Teorii Literatury - uczniowie Ireneusza Opackiego. Jeśli o tym pamiętać, to w „śląskiej mikrologii” można zobaczyć kontynuację, a może tylko odnogę, szkoły „sztuki interpretacji”, założonej przez naszego Mistrza w połowie lat 70. XX w. Konieczne jest zastrzeżenie, że Opacki nie przepadał za tym, co malutkie, ścieśnione, piskliwe; jako wybitny interpretator romantycznych arcydzieł zwykł dystansować się wobec estetycznych ograniczeń poprzedniej epoki - sentymentalnej emocjonalności, rokokowych perwersji czy klasycystycznej pedanterii. Ale wykłady i artykuły lubił zaczynać od prezentacji zjawisk z pozoru błahych lub banalnych, jak choćby „brązowniczy” wierszyk Lechonia (Śmierć Mickiewicza), nowelka Prusa Z legend dawnego Egiptu (skromna przymiarka do Faraona) albo epilog do Pana Tadeusza (kłopotliwy dodatek do epopei, dawniej pomijany przez wydawców $)^{5}$. W toku interpretacji owe teksty pomniejsze ni stąd, ni zowąd zyskiwały blask autentycznej wielkości, Opacki wywoływał efekt wzniosłości, brawurowo posługując się dialektyką tego, co wielkie i małe. $\mathrm{W}$ tym momencie warto przypomnieć, że jego nauczycielem był Czesław Zgorzelski, autor pionierskich studiów poświęconych miniaturom Słowackiego i Mickiewicza, w których obsesyjnie próbował zrozumieć tajemnicę potężnego oddziaływania lirycznych drobin, fragmentów i strzępów (oglądanych $\mathrm{z}$ dociekliwością formalisty) ${ }^{6}$.

Nic dziwnego, że mając takich nauczycieli, preferowaliśmy teksty interpretacyjne poświęcone polskiej poezji; w naszym "czteroksięgu” znalazły się bloki monograficzne poświęcone Mickiewiczowi i Leśmianowi, trzy studia o Białoszewskim i seria szkiców, których bohaterami byli poeci XX wieku (kolejno: Grochowiak, Barańczak, Pawlikowska, Sztaudynger, Wojaczek, Wat, Bujnicki, Kamieńska, Miciński, Szymborska, Baczyński, Różewicz, Zagajewski, Rymkiewicz). A jeśli prozaicy, to bliżsi modelu prozy poetyckiej, zaczynając od Haupta i Schulza (po dwa szkice), potem Gombrowicz, Tyrmand i Huelle. Obok tekstów analitycznych i historycznych pojawia się kilka prób teoretycznych, szczególne istotne są prezentacje klasyków: Sztuka mikrolektury Rolanda Barthes'a (A. Dziadek), Mikroskopia Romana Jakobsona oraz Przyziemne intuicje. Carlo Ginzburga „Znaki, oznaki, poszlaki” (B. Mytych). Wykraczaliśmy poza literaturę rodzimą w stronę rzymskiego antyku (Z. Kadłubek, E. Buksa), literatury angielskiej (P. Ję-

\footnotetext{
${ }^{4}$ Por. Czarne krasnoludki. Zamiast wstępu... Z Aleksandrem Nawareckim rozmawiają Beata Mytych Forajter i Iwona Gralewicz-Wolny, [w:] Par Coeur. Twórczość dla dzieci i młodzieży raz jeszcze, Katowice 2016, s.19-20.

${ }^{5}$ Więcej na ten temat pisałem w: Skarb w Srebrnym Jeziorze. O sztuce retorycznej Ireneusza Opackiego, [w:] Znajomym gościńcem. Prace ofiarowane Profesorowi Ireneuszowi Opackiemu, red. T. Sławek, Katowice 1993, s. 181-190.

${ }^{6}$ Portret lubelskiego mikrologa próbowałem nakreślić w szkicu: Dumania w dzień odjazdu. O tonie elegijnym Czesława Zgorzelskiego, [w:] Polonista na katedrze, red. M. Łukaszuk, Lublin 2017 [w druku].
} 
drzejko), francuskiej (J. Ryba, M. Nowotna), rosyjskiej (P. Fast) i austriackiej (E. Hurnikowa); a były też transkontynentalne wycieczki - do Ameryki i Japonii (A. Kunce). Ta ostatnia autorka włączyła w krąg refleksji świat kina, K. Mokry grafikę, J. Leociak - fotografię. Wśród nielicznych gości spoza UŚ warto podkreślić udział Romana Koropecky’ego. Amerykański autor monumentalnej biografii (Adam Mickiewicz. The Life of a Romantic, Ithaca-London 2008) dał nam studium o „robakach” w Panu Tadeuszu, z którym koresponduje Pchła-zapomniany temat erotyczny dawnej poezji, ekscentryczna rozprawka Radosława Grześkowiaka zapowiadająca jego zookrytyczną monografię (Amor Curiosis, Gdańsk 2013). Cieszy też obecność prekursorów rodzimej mikrologii: Piotra Michałowskiego, jako autora Miniatury poetyckiej (Szczecin 1999) oraz Jacka Leociaka, współautora [wspólnie z B. Engelking], mikrohistorycznej „encyklopedii": Getto warszawskie. Przewodnik po nieistniejącym mieście (Warszawa 1997).

\section{Co to jest mikrologia?}

W serii czterech tomów znalazły się też trzy moje wypowiedzi programowe, komentujące kolejne fazy "mikrologicznej” przygody - od wstępnych założeń, przez próbę opisania zjawiska, po finalne podsumowanie i zamknięcie. Inicjalna wypowiedź (Mikrologia, genologia, miniatura $)^{7}$ pierwotnie przygotowana została na sesję genologiczną, stąd punktem wyjścia były elementarne pytania - czy gatunki można pomniejszać? Czy sensowny jest podział na „duże” i „małe”? Wbrew pozorom kwestie dotyczące skali są trudne i podstępne (nawet dla inżynierów). Jedyny badacz „tekstów o małej pojemności”, Jan Trzynadlowski, pisząc Małe formy literackie (1977) zatrzymał się na poziomie opisu i ogólnym wrażeniu, że cywilizacyjne przyspieszenie dyktuje skrótowość i zwięzłość form. Subtelniejszy autor Miniatur poetyckich skupił się na liryce, słusznie eksponując kategorię „miniatury”, ale uwadze Michałowskiego uszła etymologia tytułowego terminu, który wbrew pozorom nie wywodzi się od łacińskiego przymiotnika minimus (mały), lecz od „minii” (tlenek ołowiu), czerwonego barwnika, którym średniowieczni miniatorzy wypisywali najważniejsze partie tekstu, teologiczne pojęcia, ważne myśli i symbole. Gotycka miniatura, nie oznaczała dziełka o skromnych rozmiarach, lecz - istotność, a nawet wyjątkowość samego komunikatu. Zaskakująca wymowa tego terminu jest sygnałem, że myślenie o tym, co miniaturowe cechuje subtelność, nieuchwytność, a nawet paradoksalność. Ten wątek doczekał się rozwinięcia we Wstępie do drugiego tomu, gdzie próbie definicji wymykało się pojęcie mikrologii: „nie mamy władzy nad tym słowem bliskim neologizmu, nie wiemy jak jest rozumiane, ani czym będzie w przyszłości”. Ale miałem wtedy pewność, że nie chodzi tu o „nową metodę” (bo ani nowa, ani metodyczna); wymiar „mikro” można odkryć niemal w każdej teorii, we wszelkich aktach dociekliwej obserwacji czy analizy - „I ty możesz zostać mikrologiem!”. Po tak demokratycznym i gościnnym otwarciu pojawiły się obawy przed łatwością, a nawet trywializacją naszych praktyk, stąd ostrzejszy ton eseju wieńczącego cykl - Czarna mikrologia. W tytule słychać echo lektury Czaplińskiego, ale skala mikro nie łączy się tutaj ze śmiercią, lecz ze wzniosłością sztuki nowoczesnej (J.-F. Lyotard), a także z codziennością, która „Ma wymiar drobny. Częstotliwość dużą. Jest niezauważalna" (J. Brach-Czaina). Trzeci aspekt to technika, kontekst absolutnie podstawowy, choć dotąd pomijany; a przecież wszystko zaczęło

\footnotetext{
${ }^{7}$ Por. A. Nawarecki, Mikrologia, genologia, miniatura, [w:] Miniatura i mikrologia literacka, red. A. Nawarecki, Katowice 2000, s. 9-28.

${ }^{8}$ A. Nawarecki, wstęp do: Miniatura i mikrologia literacka, t. 2, red. A. Nawarecki, Katowice 2002, s. 8.
} 
od mikroskopu (odsłaniającego otchłań mikrokosmosu), zaś kończy potęgą coraz nowszych i doskonalszych nanotechnologii. Mikrologia w stylu noir odsłania jakąś grozę i brutalność; może był to efekt uboczny moich utarczek z „wielkością” Mickiewicza, bo czy poloniście godzi się „pomniejszać” wieszcza?

W tym momencie wracam do pierwszego szkicu z tomu Maty Mickiewicz, w którym krytycy najchętniej dostrzegali wykładnię mikrologii. Michał Paweł Markowski jej dominantę zobaczył w romantycznej aurze (tajemniczej i baśniowej), której patronować powinien - co zaskakujące - duet filozofów Benjamin / Adorno, wraz z przesłaniem: „mikrologia jest dla metafizyki ocaleniem przed zakusami myśli łapczywej”’. Beata Gontarz skłonna była tu raczej widzieć „domorosły odpowiednik czy prywatny wariant dekonstrukcji”, a jako patronów Derridę i Hillisa Millera ${ }^{10}$.

\section{Bóg jest mały}

We wspominanych projektach obok autorytetów filozoficznych przywoływałem też teologów: od Pseudo-Dionizego po św. Teresę z Lisieux (Małą Tereskę), która w roku 1997 została ogłoszona doktorem Kościoła, jednak wątek teologiczny, a raczej kryptoteologiczny, nie doczekał się rezonansu. $\mathrm{Z}$ tym większym zdziwieniem odnotowuję zdarzenie, jakie miało miejsce na terenie województwa śląskiego (bo administracyjnie należy do niego Częstochowa), gdzie 17 sierpnia 2016 r. świętowano jubileusz 1050. rocznicy chrztu Polski. Tę wielką uroczystość religijno-państwową obchodzono na Jasnej Górze z monumentalnym rozmachem; z udziałem episkopatu, prezydenta, rządu, parlamentarzystów, korpusu dyplomatycznego, kilkuset tysięcy wiernych i dziennikarzy z całego świata akredytowanych na Światowe Dni Młodzieży. Najważniejszy gość, papież Franciszek, wygłosił okolicznościową homilię, której chciałbym przyjrzeć się bliżej, także dlatego, że przeszła bez echa. Być może zaważył przewodni motyw, przymiotnik piccolo, powtórzony co najmniej dziesięciokrotnie ${ }^{11}$. Intensywna obecność słowa „mały” wzmocniona podobnymi epitetami (prosty, zwyczajny, skromny, cichy, dyskretny), tak dalece bardzo zdominowała homilię, że zabrakło w niej wielkiej historii (nawet Mieszka i Dąbrówki, których dziejową rolę zajęły nasze „matki i babcie”). Spośród narodowego Panteonu pojawili się tylko Faustyna Kowalską i Karol Wojtyła, jako pokorni głosiciele tajemnicy Miłosierdzia usytuowani w kręgu „maluczkich” (Jan Paweł Wielki - jako „skromny i cichy” święty!) Ale nie może być inaczej, skoro „objawienia się Boga ma zawsze miejsce w małości”; największe wydarzenie - boskie wcielenie w człowieka - nie dokonało się tryumfalnie, lecz w sposób niezauważalny dla świata. Pan „jest najmniejszym z nasion” (Mk 4,31), był też małym dzieckiem, zaś pierwsze objawienie boskości, przemiana wody w wino, okazało się „prostym cudem”, tym skromniejszym, że wydarzył się w przestrzeni „małej wioski”, wśród biednych, anonimowych ludzi. I właśnie „prosty cud” (to oksymoron!) obrał papież za temat jubileuszowej homilii, gdyż tego dnia w Częstochowie działo się to samo co w Kanie (nie inaczej musiało być na dworze Piastów) - wesoło, wśród rodziny i przyjaciół, za stołem, przy winie: „Bóg zbawia stając się małym, bliskim i konkretnym. Przede wszystkim Bóg czyni się małym”.

\footnotetext{
${ }_{9}^{9}$ Por. M.P. Markowski, Miłe/Małe, „Tygodnik Powszechny” 2004, nr 44, s. 13.

${ }^{10}$ B. Gontarz, Dekonstruowanie Mickiewicza, [w:] Adam Mickiewicz. Dwa wieki kultury polskiej, red. K. Maciąg, M. Stanisz, Rzeszów 2007, s. 570.

${ }^{11}$ Cyt. za: Wszystkie wystapienia papieża Franciszka w Polsce, <www.deon.pl> [dostęp: 30.06.2017].
} 
Zaskakująca przemowa, jej korzenie oczywiście tkwią w ewangelii, komentowanej radykalnie w apoftegmatach ojców pustyni, a potem przez teologię negatywną. Drugie źródło to myśl św. Franciszka, apologety „braci mniejszych”, co zrozumiałe w wypadku papieża, który obrał imię Biedaczyny z Asyżu. Wreszcie kontekst jezuicki, dotyczący osobistej mikrologii św. Ignacego, której istotę wyrażać ma napis rzekomo wyryty na jego grobie: „Non coerceri maximo contineri tamen a minimo, divinum est" (Nie dać się ograniczyć nawet przez to, co największe, a jednak zawierać się w tym, co najmniejsze - Boska to rzecz). Autorem tej sentencji nie jest Loyola; to zakonny apokryf spopularyzowany przez Hölderlina, który obrał go za motto poematu Hyperion ${ }^{12}$. Papież Bergoglio dobrze zna ten fragment, cytował go publicznie, także w wersji Hölderlinowskiej, w oryginale i z pamięci. Nauczyć się na pamięć, znaczy to samo, co „Wziąć sobie do serca”, dopowiada Derrida, myśląc o poemacie, który powinien być serdecznie uwewnętrzniony, połknięty, zwinięty w kłębek ${ }^{13}$. „Poemat powinien być krótki, z natury swej eliptyczny", zaś Bóg objawia się mały.

\section{Czy mikrologia jest innowacyjna?}

Kontekst teologiczny, a bardziej może religijny i dewocyjny warto dopełnić, czy skontrastować, perspektywą współczesnej nauki. Istotne pytanie o „innowacyjność śląskiej mikrologii” postawiła bowiem ostatnio Ewelina Suszek; w swoim obszernym i dociekliwym studium zastanawia się nawet „czy ma szansę stać się modną praktyką interpretacyjną"14? Tę kwestię rozważa w świetle teorii Wallensteina („nowatorstwo przywilejem centrum”) i „peryferyjnej” koncepcji Floridy, lecz z za kryterium rozstrzygające uznała innowacyjność zdefiniowaną przez Ryszarda Nycza, której pierwszym warunkiem jest „oryginalne rozwiązanie istotnego merytorycznie problemu”, drugim "wypracowanie powtarzalnej procedury”, trzecim osadzenie „w sposobie, który prowadzi do odkrycia pola problemowego”, a wreszcie - „zainicjowanie nowej dziedziny".

Sporo argumentów przemawia za, ale nie do końca, bo sami mikrolodzy uchylają się od przywileju pionierstwa: „Próbowaliśmy tylko zintegrować 'mikropoetykę' Gastona Bachelarda, 'mikrolekturę' Jeana-Pieere'a Richarda, Jakobsonowską 'mikroskopię' i Barthesowską teorię punctum oraz inne jeszcze koncepcje 'mikropoetyki' czy 'fenomenologii mikroskopowej', spotykane na pograniczu krytyki literackiej i filozofii - w pismach Waltera Benjamina, Theodora Adorno, Jacques'a Derridy, Jean-Francois Lyotarda"15. Suszek w tym wyznaniu dopatruje się „intrygującej fuzji, zaskakującej hybrydy, innowacyjnego często połączenia modnych często tendencji"; podobne sojusze między humanistyką i naukami ścisłymi zdarzają się nawet w Polsce, „ale naukowy tryumf odnieśli mikrobiolodzy, mikrofizycy i mikroekonomiści” ${ }^{16}$. Badaczka docenia innowacyjny wysiłek przeniesienia tej inspiracji w obręb literaturoznawstwa, ale zauważa też dekonstrukcyjną kontrę, programową niechęć do powtarzania sprawdzonej procedury, hołdowanie raczej duchowi inwencji niż powtarzalnej innowacji. Dlatego

\footnotetext{
${ }^{12}$ Por. M. Bednarz, Sekret osobowości św. Ignacego Loyoli, [w:] I. Loyola, Pisma wybrane. Komentarze, t. 2, Kraków 1968, s. 570; A. Spadero, Ignacjańskie korzenie reformy Kościoła papieża Franciszka, przeł. J. Poznański, „Posłaniec Serca Jezusowego” 2016, nr 8.

${ }^{13}$ J. Derrida, Che cos’è la poesia?, przeł. M.P. Markowski, „Literatura na Świecie” 1998, nr 11-12, s. 156.

${ }^{14} \mathrm{E}$. Suszek, Moda na małe? Innowacyjność śląskiej mikrologii literackiej, „Postscriptum Polonistyczne” 2016, nr 1, s. 179-191.

${ }^{15}$ A. Nawarecki, Maty Mickiewicz, Katowice 2003, s. 11.

${ }^{16}$ E. Suszek, Moda na małe?..., s. 180.
} 
za kryterium jej wdrożenia próbuje uznać ważny dla humanistyki status „mody intelektualnej”, ale i tu pojawiają się rozterki, bo naśladowców śląskiego „mikro” znajduje w Kielcach, ale trudniej ich wypatrzyć w Krakowie ${ }^{17}$.

Do rozważań nad innowacyjnością naszej mikrologii dodałbym argument pojawiający się w studiach E. Rogersa i innych badaczy innowacyjnych dyfuzji, przekonanych, że ich istotę doskonale wyraża opinia Schopenhauera dotycząca trzech faz poznawania prawdy: „Z początku uznaje się ją za absurd. Potem budzi silny sprzeciw. W końcu staje się czymś oczywistym"18. A skoro tak, to miło mi donieść, że założycielski tekst Mikrologia, genologia, miniatura, wygłoszony na XXIX Konferencji Teoretycznoliterackiej (zorganizowanej przez mój macierzysty Zakład i Pracownię Poetyki Historycznej IBL PAN 17-22 IX 1999 w Cieszynie), nie został dopuszczony do druku w pokonferencyjnym tomie Genologia dzisiaj (red. W. Bolecki, I. Opacki, Warszawa 2000). Nie udało mi się uzyskać dostępu do recenzji, ale pochlebiam sobie przypuszczeniem, że referat wydał się absurdalny i wywołał sprzeciw.

\section{Mikropoetyckie początki}

Skoro rozpiera mnie pycha „inicjatora” śląskiej mikrologii, to na tej fali spróbuję wskazać początkowy impuls. Pierwszym terminem, zapewne przejętym od Bachelarda lub Bachtina była „mikropoetyka”. Nie było to natchnienie, raczej pochylenie, bo wszelka działalność mikropoetycka jest przyziemna; w stylu franciszkańskim robimy to, „schylając głowę, by brzuchem chodzić po ziemi", a wedle filologicznej reguły - z nosem w papierach ${ }^{19}$. Dla Zgorzelskiego, założycielskim momentem mikrologicznym, zdaje się spotkanie z rękopisem liryków lozańskich - nieczytelnie zabazgranym arkusikiem, sponiewieranym świstkiem, na który trafiły najpiękniejsze wiersze Mickiewicza (de facto tylko fragmenty). Sam doświadczyłem podobnych emocji, rachując lozańskie kropki i przecinki, ale wcześniej zaskoczyły mnie wiersze księdza Baki wyczytane z jedynego zachowanego egzemplarza Uwag śmierci niechybnej (1766). Kontakt $\mathrm{z}$ dotkliwie zaczytanym druczkiem jarmarcznym, dawał pewność, że pierwodruk stanowczo różni się od powszechnie znanej wersji tekstu (anonimowa edycja Uwag z roku 1807). W oryginale wileński jezuita układał swe wiersze w formie regularnej strofy $(8+8+6+6)$ :

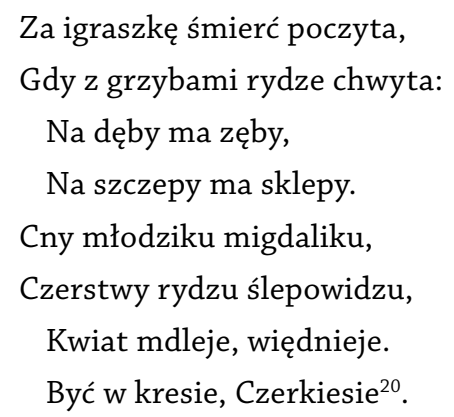

${ }^{17}$ Suszek wskazuje przypadek recepcji śląskiej mikrologii (A. Wileczek, Świadectwa - ślady - znaki. Lapidarium jako strategia formy, Kielce 2010) i jej pominięcia (A. Zawadzki, Obraz i ślad, Kraków 2014).

${ }^{18}$ Cyt. za: A. Buchowski, J. Strycharz, Innowacja i komercjalizacja wiedzy a nauki społeczne, [w:] Nauki społeczne a komercjalizacja wiedzy. Jak humaniści tworzq innowacje dla gospodarki i społeczeństwa, red. S. Rudnicki, Kraków 2013, s. 22.

${ }^{19}$ Por. M. Jochemczyk, Wobec tradycji. Ślaskie szkice oikologiczne, Katowice 2015; Z. Kadłubek, Bezbronne myśli. Eseje i inne pisma o Górnym Śląsku, Katowice 2016.

${ }^{20}$ J. Baka, Uwagi, oprac. A. Czyż, A. Nawarecki, Lublin 2000, s. 62. 
Tymczasem nowy wydawca, satyryk Julian Korsak, chcąc uzyskać komiczny efekt, rozpisał ten ośmiowiersz na serię kadłubowych wersów:

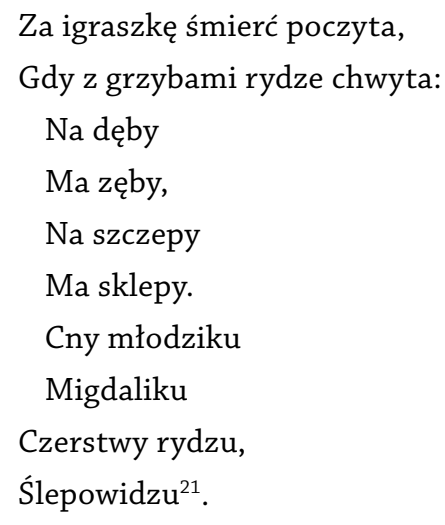

W ten oto sposób osiemnastowieczny rymopis stał się autorem „tasiemcowych” wierszy przypominających niekiedy awangardowe „schodki”. Zmistyfikowany Baka używał nie tylko unikatowych czterozgłoskowców, ale też miary trójwersowej - niestosowanej w polskiej wersyfikacji. Jego słynny „kusy” wiersz, nazywany też „siekańcem”, uwydatniony hałaśliwym rymem okazał się poetyckim skandalem, budził wesołość lub pogardę, tym większą, że podrygujące wierszyki mówiły wyłącznie o śmierci i umieraniu. Baka wkrótce zyskał opinię najgorszego grafomana polskiej literatury, potem dziwaka, którym fascynowali się romantycy (Mickiewicz, Syrokomla, Kraszewski), zaś dla poetów nowoczesnych (Pawlikowska, Wat, Czechowicz, Miłosz, Twardowski, Rymkiewicz) stał się poetą absolutnie fenomenalnym.

Nie byłoby legendy Baki, ani przemiany wierszoklety w geniusza, gdyby jego strofika i wersyfikacja nie zostały „posiekane” na miazgę. I właśnie to mikropoetyckie wydarzenie w skali zwrotki, wersu i rymu przyniosło skutki wręcz niewyobrażalne! W kontekście Bakowskiej „umieranki” widać dojmująco, że mikrologia nie ogranicza się do małości, niemniej ważny jest aspekt degradacji, odrzucenia, a nawet wstrętu (status fragmentów, ułamków, okruchów, resztek, odpadów, odchodów, ochłapów itp.) W perspektywie filologa najważniejsze będzie jednak skupienie na graficznym, morfologicznym czy stylistycznym detalu, bo to otwiera oczy na świat, nie tylko świat literatury.

\footnotetext{
${ }^{21}$ Baka odrodzony. Uwagi o śmierci niechybnej wszystkim pospolitej, oprac. W. Syrokomla, Wilno 1855, s. 96-97.
} 


\title{
SŁOWA KLUCZOWE:
}

\author{
m i k rologi a
}

\begin{abstract}
AbSTRAKT:
Tekst przypomina historię badań „mikrologicznych” na Uniwersytecie Śląskim w Katowicach: 3 tomy zbiorowe Miniatury i mikrologii literackiej 2000-2003; Skala mikro w badaniach literackich (2005) i książkę redaktora cyklu A. Nawareckiego Maty Mickiewicz (2003) oraz monografie J. Ryby, B. Mytych, A. Kunce, W. Bojdy. W serii uczestniczyło 40 autorów, studia nad tym, co drobne, znikome i wzgardzone patronują mistrzowie „sztuki interpretacji” I. Opacki i Cz. Zgorzelski. Szkoła śląska porównywana jest z poznańską (E. Domańska, P. Czapliński), rozważa się jej innowacyjny charakter, zakorzenienie regionalne i prowincjonalne, początkowy impuls filologiczny („mikropoetyka" Baki) oraz konteksty historyczne, polityczne, religijne (teologia piccolo papieża Franciszka).
\end{abstract}




\section{SILEZJOLOGIA}

\section{mikropoetyka}

\section{NOTA O AUTORzE:}

Aleksander Nawarecki - prof. dr hab., kierownik Zakładu Teorii Literatury na Uniwersytecie Śląskim; badacz osobliwości, edytor i komentator poezji ks. Baki (Czarny karnawał, Wrocław 1991), autor prac o roślinach i zwierzętach w literaturze (Pokrzywa, Chorzów-Sosnowiec 1996), o przedmiotach (Parafernalia, Katowice 2014), esejów Mickiewiczowskich (Mały Mickiewicz, Katowice 2003) i silezjologicznych (Lajerman, Gdańsk 2011). Współautor podręcznika Przeszłość to dziś (Warszawa 2003), redaktor serii Miniatura i mikrologia literacka (Katowice 2000-2003) oraz Historycznego słownika terminów literackich (w przygotowaniu). 